\title{
Monetary Policy and Trade Openness in Ghana
}

\author{
Anthony Chiaraah \\ Department of Economics \& Entrepreneurship Development, \\ University for Development Studies, Wa, Ghana. \\ tonyacgh@yahoo.com \\ DOI//http://dx.doi.org/10.4314/gjds.v16i2.12
}

\begin{abstract}
Monetary policy is one of the key drivers of economic growth in most economies and through its impact on economic variables. The objective of this study is to analyse the effectiveness of monetary policy in Ghana taking into account the role of trade openness and trade policy in influencing the effectiveness of monetary policy. The study employed the co-integration approach with quarterly data from 2002 to 2016 to assess the relationship between trade openness and effectiveness of monetary policy in affecting inflation and output. The empirical result revealed that as the degree of trade openness increases, monetary policy become less effective in reducing the rate of inflation and causes domestic output to decline in the long-term. Though the results of the study confirmed the theoretical relationship between trade openness and inflation and output, the results indicated that when monetary policy is taken into account, negative effect of trade openness on inflation is reduced. The ability of trade openness to reduce inflation level in Ghana is hindered by increases in the monetary policy rate. Thus, the results implies that trade openness hinders monetary policy's ability to curtail inflation in Ghana whilst it is able to effectively cause output to decline.
\end{abstract}

Keywords: Monetary Policy, Inflation, Output, Trade Openness, Co-integration

\section{INTRODUCTION}

Monetary policy is one of the most important and key drivers of economic growth in most nations. A number of nations in order to achieve macroeconomic stability has over the years use monetary policy as a means to achieving this goal. Monetary policy can be either expansionary or contractionary. Contractionary monetary policy is where monetary policy is used to reduce the amount of money in circulation and as expected contractionary monetary is expected to cause reduction in inflation rate (Dornbusch \& Giovannini, 1990; Taylor, 1993; Woodford, 2001). 
Policy makers and researchers have over the years been concerned about the ability of monetary policy to effectively achieve its goals and objectives (see for example, Abradu-Otoo, Amoah, \& Bawumia, 2003; Bawumia, 2010; Karras, 2001; Taylor, 1993)

Economic theory also suggests that the ability of any monetary policy to effectively affect inflation and output to some extent depends on how opened that economy is ( Karras, 1999, 2001). Karras (1999, 2001) argued that, in an open economy, an expansionary monetary which is a policy used to increase the amount of money in circulation and this policy would have greater effect on price level and lesser effect on output, due to the expected depreciation that is associated with expansionary monetary policies. Concerning the effects, such expansions would rather increase general price levels with lesser effect on output levels. Similarly, Berument, Konac, and Senay (2007) also maintained that the effect of monetary policy in an open economy depends on the way exchange rate affects input prices, inflationary expectations and wage formation. For instance, exchange rate depreciation after an expansionary monetary policy results in higher input prices, higher prices for imported consumer goods and higher wage demands. This tends to increase the impact of monetary policy on consumer prices.

The Ghanaian economy is characterised by import domination, inflation targeting policy regime as opposed to monetary targeting and managed float exchange rate regime, which is quite different from other countries that have been studied. An empirical work that looks at Ghana's specific situation in terms of the extent to which the degree of openness affects the effectiveness of monetary policy has become very critical for policy makers. This is particularly necessary because, Ghana has since 1983 implemented a number of policies to liberalise the economy. Since the implementation of the Economic Recovery Programme (ERP) in 1983, with one of the key policy of opening up the economy, Ghana's trade with the rest of the world has been on the increase. For example, Ghana's trade as a percentage of Gross Domestic Product (GDP) rose from 11.5 percent of GDP in 1983, to over 110 percent in 2001, but this has declined to about 88 percent in 2016. An interesting aspect of the expansion in Ghana's trade over the years has been the fact that imports of goods and services has always exceeded exports as shown in figure 1.

The Ghanaian economy therefore presents a different economic situation (in terms of policy instrument and its composition of trade over the years) to what have been examined in the literature, hence the need to specifically examine the extent to which openness to trade affects the effectiveness of monetary policy in Ghana. The objective of this study is to analyse the effectiveness of monetary policy in Ghana taking into account the role of trade openness and trade policy in influencing the effectiveness of monetary policy. Monetary policy is effective when it has significant 
impact on inflation and output. The rest of the paper is organised as follows: section 2 gives a stylised facts on trade and monetary policy in Ghana. Section 3 deals with theoretical and empirical literature. Section 4 presents data employed in the study and description of the empirical methodology. Section 5 presents the empirical results and discussions and the final section provides the conclusions and policy recommendations drawn from the study.

\section{Stylised Facts on Trade and Monetary Policies in Ghana}

\section{Ghana's Trade Policy}

Since the early 1950s, there has been debate over the appropriate trade policy for developing countries (Todaro, 1992). The contention has been between free market advocates and trade protectionists. While the free market proponents support an outward-looking, export-oriented trade regime, the trade protectionists settle for an inward-looking system. They both nevertheless agree that industrialisation should be the dominant economic development strategy.

Ghana's trade strategy after independence was import substitution industrialisation, a strategy aimed at reducing the economy's dependence on trade. The period saw the establishment of State-Owned Enterprises (SOEs) in critical sectors of the economy and their involvement in almost every aspect of the economy, ranging from agro-based industries to manufacturing companies. Unfortunately, this policy could not be sustained following the overthrow of the First Republic in 1966. Consequently, by 1970 the country's trade balance was in deficit. However, there was a quick reversal by 1972 and largely throughout the 1970 s as the trade balance improved on the back of increased domestic food production.

Since independence, Ghana's trade policy has evolved through many different phases. Prior to 1983 the issuing of import and export licences was mainly controlled by the central government. In addition, the country had a fixed exchange rate regime which was adjusted for the purpose of international trade (Oduro, 2000). Following the implementation of the ERP in 1983, the country gradually liberalised its trade with the rest of the world by removing import and export licencing regimes and liberalising the exchange rate market.

Since the implementation of the economic reforms in 1983, the rate of international trade has been on the rise. The average trade to GDP ratio between 2002 and 2016 (85.1 percent of GDP) is 14 percent higher than the average trade to GDP ratio between 1990 and 2001 (71.11 percent of GDP). Export and import demand of the country has also seen a consistent rise since 2002 as shown in figure 1. 


\section{Figure 1: Exports and imports in Ghana}

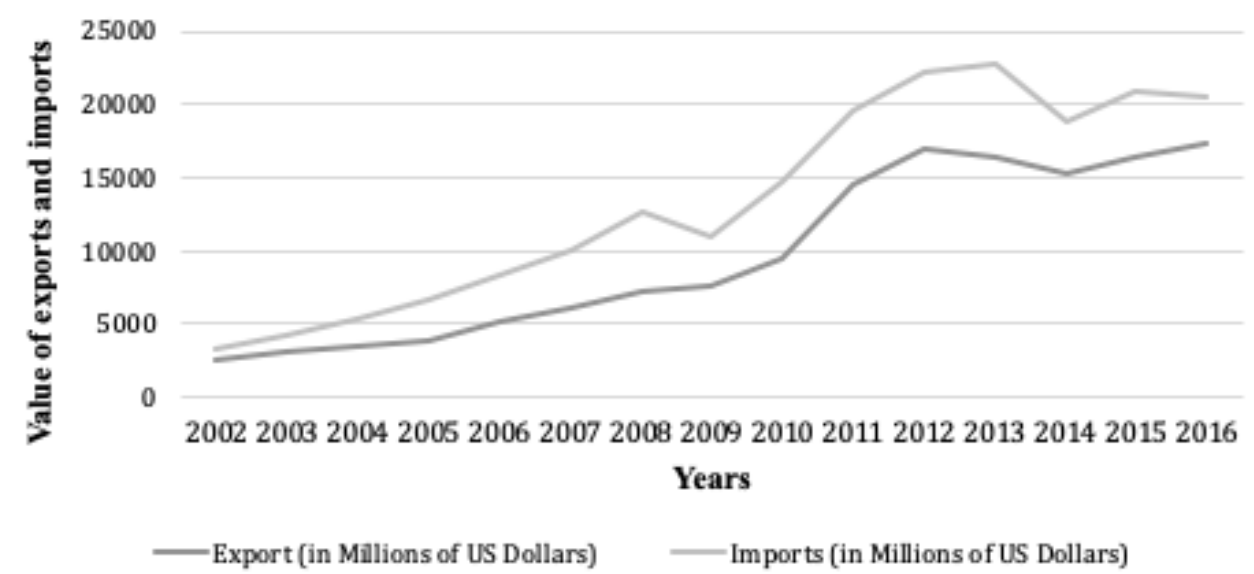

Source: Various Editions of Bank of Ghana Annual Report

Though exports have been on the increase in Ghana's economy, it is has been dominated largely by the export of primary commodities such as Gold, Cocoa, Timber and Oil. These commodities together constitute more than 80 percent of Ghana's total exports. When it comes to imports, more than 90 percent of Ghana's imports from the rest of the world is made up of finished goods, which sometimes includes necessities of life such as machinery, equipment and food products. The composition of Ghana's exports and imports makes the economy very vulnerable to external shocks. Thus, there is the need for strong fiscal and monetary policy framework that would be able to cushion the economy from such shocks anytime they occur.

\section{Monetary Policy}

From independence to date, Ghana's monetary policy has evolved from direct control regime in which, the central bank directly regulated interest rates and the supply of money in the economy, to an indirect control regime as part of the liberalisation process of the economy. Under the indirect monetary control regime, the Bank of Ghana used market instruments to influence interest rates and the supply of money in the economy.

Under the new Bank of Ghana Act (2002), the primary goal and objective of the Bank of Ghana is the pursuit of price stability. The monetary policy setting of the Bank is that of a small open economy model, with several practical complications specific to the Ghanaian economy: 
- About 50\% of GDP is used to bring in imported goods, with most of the transactions denominated is US dollars

- The exchange and payments system is a liberal one and the exchange rate is freely floating and interest rates are fully liberalised

- Significant portions of the deficits are typically financed on the domestic market through the issue of Treasury bills

- Strong inertial inflationary expectations have become embedded in the economy due to history of high inflation and exchange rate volatility. This has allowed dollarisation to take hold, with significant foreign exchange deposits being held in the banking system.

- A large proportion of the money stock is held outside the banking system and is highly dependent on the cocoa season

- Any shifts in local investor and bank confidence, be these the result of an exogenous shock (e.g. a spike in oil prices) or a weakening in policies, have rapid repercussions.

Under the new Bank of Ghana Act (2002), a Monetary Policy Committee (MPC), which is in charge of formulating monetary policy (primarily setting interest rates), has also been established. The MPC has placed the process of monetary policy formation in Ghana on a more analytical and transparent footing.

Bawumia and Amoah (2008) in their study on monetary policy found that the relationship between inflation and monetary aggregates, which was the main target of monetary policy, had weakened over time. Thus, monetary policy decisions under the indirect monetary policy regime had no significant effect on the attainment of price stability and growth.

To address the weakness in the indirect regime system, in 2002, the Bank of Ghana adopted the inflation targeting policy framework, though formal announcement was made in 2007. Under this policy framework, the Bank of Ghana used the monetary policy rate to directly target inflation without using the route of monetary aggregates. After the adoption of the inflation-targeting regime, the rate of inflation has seen a consistent decline. According to the World Bank (2016), inflation rate, which averaged 27.9 percent between 1992 and 2001 (period of monetary targeting), declined to about 14 percent between 2002 and 2016 (period of inflation targeting).

\section{Theoretical and Empirical Literature}

The Marshall Lerner Condition shows the conditions under which a change in the exchange rate of a country's currency leads to an improvement or worsening of a country's balance of payments. This states that, for a currency devaluation to lead 
to an improvement (for example, reduction in deficit) in the current account, the sum of price elasticity of exports and imports (in absolute value) must be greater than one. Marshall-Lerner condition is a phenomenon that describes increase in net exports through depreciation of domestic currency. When the sum of export and import elasticities are greater than unity, this condition states that a deficit in the trade balance may be improved through currency depreciation at least in a long run.

Marshall Lerner condition which was propounded by Alfred Marshall and Abba Lerner reveals that if the sum of absolute values of a country's export and import price elasticities are greater than one, devaluation of national currency provides advantage that country's trade balance. The trade balance of a country is obtained from the absolute value of its export minus the absolute value of its imports. If currency is devaluated, export prices decrease causing an increase in export volume and import prices increase causing a decrease in import volume of the country. Export or import quantities need to respond adequately to compensate for the worsening price, .a requirement for trade balance to be positively affected by devaluation. The sum of the elasticities in absolute value of export price and import price must be greater than 1 in order to influence devaluation that can improve the country's trade balance.

A trilemma suggests that countries have three options from which to choose when making fundamental decisions about managing their international monetary policy agreements. However, the options of the trilemma are conflictual because of mutual exclusivity, which makes only one option of the trilemma achievable at a given time.

When making fundamental decisions about managing international monetary policy, a trilemma suggests that countries have three possible options from which to choose. According to the Mundell-Fleming trilemma model, these options include:

1. Setting a fixed currency exchange rate

2. Allowing capital to flow freely with no fixed currency exchange rate agreement

3. Autonomous monetary policy

A fundamental contribution of the Mundell-Fleming framework is the impossible trinity, or the Trilemma. The Trilemma states that a country may simultaneously choose any two, but not all of the following three policy goals - monetary independence, exchange rate stability and financial integration. Each of the three sides of the triangle, representing monetary independence, exchange rate stability, 
and financial integration, depicts a potentially desirable policy goal. However, it is not possible to be on all three sides of the triangle simultaneously.

A review of theoretical and empirical literature also analysed the implications of openness for equilibrium inflation rate because of discretionary monetary policy. Rogoff (1985) and Romer (1993) maintained that, the more open an economy is, the smaller the inflationary bias discretionary monetary policy will be. In a more opened economy, an expansionary monetary policy tends to have stronger effect on price levels, than on output levels. There is therefore less incentive for monetary authorities in a very open economy to use monetary expansion. However, Lane (1997) maintains that this only applies to large countries where monetary policy has the capacity to affect the terms of trade since such countries are confronted with less elastic demand for their exports. The result further indicated that unexpected expansionary monetary policy only increases production in the non-traded sector and given the fact that the share of non-traded sector in the total production is very small in a more opened economy, there is no strong incentive for monetary authorities in such economies to implement expansionary policy. Thus, Lane (1997) comes to the same conclusion that inflationary bias monetary policy is weaker in open economies.

Empirical evidence on openness and effectiveness of monetary policy is quite limited. Karras (1999) used annual data from 1953 to 1990 for a panel of 38 countries. The empirical evidence from his analysis indicated that the more open an economy, the smaller (larger) the output (inflation) effects of a given change in the money supply. The policy instrument used in the study was money supply, which is the main instrument that used under monetary targeting. The study did not examine the possible difference in the effect of interest rate which is the major policy instrument used an inflation targeting. Karras (2001) examined the effect of openness on the effectiveness of monetary policy for Australia, Canada, Germany, Italy, Japan, South Africa, UK and USA and obtained similar results. Berument et al. (2007) after examining the effect of degree of openness on the effectiveness of monetary policy for 29 countries between the 1957:2 and 2003:4 and found that the effect of openness on output and price levels differs across countries. This is due to some other factors such as exchange rate regime, the degree of independence of the central bank, monetary policy regime, the degree of capital controls among others. 


\section{Data and Empirical model}

\section{Data Source}

Data employed in this study were sourced from the World Development Indicators (2016) and Bank of Ghana (2016). Quarterly time series data on inflation rate (П), monetary policy rate $(\mathrm{R})$ and exchange rate $(\mathrm{S})$ were sourced from the Bank of Ghana. Annual data on output (GDP), Trade Openness (TO) and international trade taxes (TP) were obtained from the World Bank.

Data used for the study spanned from the first quarter of 2002 to the fourth quarter of 2016. The output gap estimated using the log ratio of output to potential output. Potential output was calculated using the Hodrick-Prescott (HP) filter.

The choice of 2002 was based, firstly, on Ghana beginning the implementation of its inflation targeting policy framework in 2002, though an official announcement was made in 2007. Secondly, beyond 2002 implies mixing two different monetary policy regimes, which may not be good for the analysis.

To assess the role of trade openness to the effectiveness of monetary policy, the study adopted the methodology as specified in the work of Hove et al. (2015):

$Y_{t}=\Phi_{0}+\Phi_{1} Y_{t-1}-\Phi_{2}\left(R_{t}-\Pi_{t+1}\right)+\Phi_{3}\left(\mathcal{S}_{t}+P_{t}^{*}-P_{t}\right)+\epsilon_{t}$

Where $\mathbf{Y}_{\mathbf{t}}$ is the output, $R_{t}$ is the short-term interest rate, $\Pi_{t}$ is the inflation rate, $S_{t}$ is the nominal exchange rate $P_{t}^{*}$ and $P_{t}$ are foreign and domestic price level respectively and $\Phi_{i s}$ are parameters that capture the effect of the various variables on the output gap.

To capture the output gap, equation (1) is re-specified as:

$Y_{t}=f\left(Y_{t-1}, R_{t}, \Pi_{t}, r \mathcal{S}_{t}\right)$

Where $r S_{t}=S_{t}+P_{t}^{*}-P_{t}$. This implies that the output gap is a function of the lag of output gap, inflation rate, short-term interest rate and real exchange rate.

Similarly, to analyse the effect of monetary policy on inflation the study adopted the Phillips curve derived from Calvo's (1983) staggered nominal price adjusting model.

The model as specified in Calvo's (1983) work is specified as follows:

$\Pi_{t}=\Omega_{1} \Pi_{t-1}+\Omega_{2} Y_{t}+\Omega_{3} Y_{t-1}+\Omega_{4}\left(\delta_{t}+P_{t}^{*}-P_{t}\right)+\Omega_{5}\left(\delta_{t-1}+P_{t-1}^{*}-P_{t-1}\right)+\varepsilon_{t}$ 
Given that inflation is influenced by its own lag, output gap and real interest rate, equation (3) is re-written as:

$\Pi_{t}=f\left(\Pi_{t-1}, Y_{t}, r \mathcal{S}_{t}\right)$

Given the objective of the study and following similar empirical works by Berument et al. (2007) and Karras (1999, 2001), we augment (2) and (4) with trade variables, short-term interest rate and budget deficit. The purpose for the inclusion of budget deficit is to capture its role in affecting the effectiveness of monetary policy (see Bawumia, 2010).

$Y_{t}=f\left(Y_{t-1}, R_{t}, \Pi_{t}, r \mathcal{S}_{t}, T O_{t}, R T O_{t}, D F_{t}, L_{t}, K_{t}\right)$

$\Pi_{t}=f\left(\Pi_{t-1}, Y_{t}, r \mathcal{S}_{t}, R_{t}, T O_{t}, R T O_{t}, D F_{t}\right)$

Where $\mathrm{TO}_{t}$ captures the level of trade openness and $\mathrm{RTO}_{t}$ is the interaction between short-term interest rate and trade openness respectively and $D F_{t}$ is the level of budget deficit in the economy. are labour and capital respectively, they are included in the output model to control for their respective roles in influencing output levels. The output and inflation models can, thus, be expressed in a linear form as in equations (7) and (8).

$$
\begin{gathered}
Y_{t}=\begin{array}{c}
\varphi_{0}+\varphi_{1} Y_{t-1}+\varphi_{2} R_{t}+\varphi_{3} \Pi_{t}+\varphi_{4} r \mathcal{S}_{t}+\varphi_{5} T O_{t}+\varphi_{6} R T O_{t}+\varphi_{7} D F_{t}+\varphi_{8} L_{t}+\varphi_{9} K_{t} \\
\quad+\mu_{t}
\end{array} \\
\begin{array}{c}
\Pi_{t}=\delta_{0}+\delta_{1} \Pi_{t-1}+\delta_{2} Y_{t}+\delta_{3} r \delta_{t}+\delta_{4} R_{t}+\delta_{5} T O_{t}+\delta_{6} R T O_{t}+\delta_{7} D F_{t}+u_{t}
\end{array}
\end{gathered}
$$

\section{Estimation Technique}

In analysing the effectiveness of monetary policy in Ghana, the study first examined the time series properties of the variables using the Augmented Dickey Fuller (ADF) test. This is supplemented by the Kwiatkowski-Phillips-Schmidt-Shin (KPSS) unit roots test. The KPSS is known to have stronger power of test than the traditional methods. Once the time series properties of the data are established, the study proceeded to estimate the effectiveness of monetary policy in Ghana using the ARDL approach to co-integration. Though ARDL approach to co-integration does not usually require the pre-testing of the order of integration of the variables being used, it is key to ensure the absence of $I(2)$ series since their presence would crash ARDL model which is meant for series that are either $I(0), I(1)$ or both.

The study adopted the ARDL approach to co-integration because to the variables employed in the study were a mixture of $I(0)$ and $I(1)$ in addition, with the time span of the data (2002Q1-20015Q4), ARDL approach to co-integration, which is known to perform well with small samples (see Pesaran, Shin, \& Smith, 2001), seem to be 
the best approach for the estimation. With respect to equation (7) and (8), the ARDL framework is specified as:

$$
\begin{gathered}
Y_{t}=\varphi_{0}+\varphi_{1} Y_{t-1}+\varphi_{2} R_{t}+\varphi_{3} \Pi_{t}+\varphi_{5} r \delta_{t}+\varphi_{6} T O_{t}+\varphi_{7} R T O_{t}+\varphi_{8} \mathrm{DF}_{\mathrm{t}}+\varphi_{9} L_{t}+\varphi_{10} K_{t} \\
+\sum_{i=1}^{P} \delta_{1 i} \Delta Y_{t-1}+\sum_{i=1}^{P} \delta_{2 i} \Delta R_{t}+\sum_{i=1}^{P} \delta_{3 i} \Delta \Pi_{t}+\sum_{i=1}^{P} \delta_{4 i} \Delta r \delta_{t}+\sum_{i=1}^{P} \delta_{5 i} \Delta T O_{t}+\sum_{i=1}^{P} \delta_{6 i} \Delta R T O_{t} \\
+\sum_{i=1}^{P} \delta_{7 i} \Delta D F_{t}+\sum_{i=1}^{P} \delta_{8 i} \Delta L_{t}+\sum_{i=1}^{P} \delta_{9 i} \Delta K_{t}+\epsilon_{t}
\end{gathered}
$$

$\Pi_{t}=\omega_{0}+\omega_{1} \Pi_{t-1}+\omega_{2} R_{t}+\omega_{3} Y_{t}+\omega_{5} r \mathcal{S}_{t}+\omega_{6} T O_{t}+\omega_{7} R T O_{t}+\omega_{8} \mathrm{DF}_{\mathrm{t}}+\sum_{i=1}^{P} \psi_{1 i} \Delta \Pi_{t-1}$

$\sum_{\substack{i=1 \\ P}}^{P} \psi_{2 i} \Delta R_{t}+\sum_{\substack{i=1 \\+v_{t}}}^{+} \psi_{3 i} \Delta \mathrm{Y}_{t}+\sum_{i=1}^{P} \psi_{4 i} \Delta r \mathcal{S}_{t_{t}}+\sum_{i=1}^{P} \psi_{5 i} \Delta T O_{t}+\sum_{i=1}^{P} \psi_{6 i} \Delta R T O_{t}+\sum_{i=1}^{P} \psi_{7 i} \Delta D F_{t}$

10

Where $\Delta$ denotes the first difference operator, $P$ is the lag order selected by the Information Criterion used, $\alpha_{o}, \varphi_{o}, \beta_{o}$ and $\omega_{o}$ are the drift parameters while $\mu_{t^{\prime}} \epsilon_{t^{\prime}} \varepsilon_{t}$ and $v_{t}$ are the error terms which are $N\left(0, \delta^{2}\right)$. The parameters $\alpha_{i s^{\prime}} \varphi_{i s^{\prime}} \beta_{i s}$ and $\omega_{i}$ are the long run multipliers and $\phi_{s}, \delta_{s}, b_{s}$ and $\psi_{s}$ are the short run parameters.

The existence of long run relationship between the dependent variables and independent variables were estimated using the bounds testing approach to cointegration. This is done by using the OLS method, which is normally the first procedure in the ARDL model. The F-test was used to test for the presence of longrun relationship among the variables in equations (9) and (10). The null hypothesis of no long-run relationship among the variables in equations (9) and (10) is tested against the alternative hypothesis of a long - run relationship. The calculated F-statistic was compared with these sets of critical values developed on the basis that the independent variables are $\mathrm{I}(\mathrm{d})$ (where $\mathrm{o} \leq d \leq 1$ ). When the calculated F-statistic falls outside the upper critical value, then a null hypothesis of no cointegration will be rejected regardless of whether the variables are I (o) or I (1) implying a long - run relationship between the variables. Once co-integration was established, the long-run and short-run error correction models were estimated. 


\section{RESULTS AND DISCUSSION}

The descriptive statistics of the variables used for the study are presented in Table $1 \mathrm{~A}$.

Table 1A: Descriptive statistics

\begin{tabular}{|l|l|l|l|l|l|l|l|l|}
\hline & $\mathrm{DF}_{\mathrm{t}}$ & $\mathrm{Y}_{\mathrm{t}}$ & $\Pi_{\mathrm{t}}$ & $\mathrm{K}_{\mathrm{t}}$ & $\mathbf{R}_{\mathrm{t}}$ & $\boldsymbol{r S}_{\mathrm{t}}$ & $\mathrm{TO}_{\mathrm{t}}$ & $\mathbf{L}_{\mathrm{t}}$ \\
\hline Mean & -5.43 & 6096.73 & 15.28 & 24.70 & 2.80 & 2.06 & 0.85 & 10.76 \\
\hline Median & -5.41 & 5814.50 & 14.93 & 24.72 & 3.03 & 1.02 & 0.87 & 10.65 \\
\hline Maximum & 6.97 & 10018.49 & 32.70 & 32.51 & 9.97 & 6.79 & 1.04 & 13.31 \\
\hline Minimum & -16.15 & 3699.30 & 8.40 & 18.68 & -9.53 & 0.85 & 0.60 & 8.56 \\
\hline Std. Dev. & 3.70 & 1902.93 & 5.50 & 3.74 & 3.45 & 1.91 & 0.13 & 1.65 \\
\hline Skewness & -0.34 & 0.42 & 1.27 & 0.22 & -0.85 & 1.33 & -0.35 & 0.15 \\
\hline Kurtosis & 6.08 & 1.91 & 5.10 & 2.02 & 4.99 & 2.94 & 1.79 & 1.52 \\
\hline Jarque-Bera & 24.87 & 4.72 & 27.21 & 2.91 & 17.19 & 17.78 & 4.90 & 5.68 \\
\hline Probability & 0.00 & 0.09 & 0.00 & 0.23 & 0.00 & 0.00 & 0.09 & 0.06 \\
\hline Sum & -325.762 & 365803.7 & 916.9867 & 1481.775 & 167.9672 & 123.6959 & 51.112 & 645.7382 \\
\hline Sum Sq. Dev. & 808.7597 & $2.14 \mathrm{E}+08$ & 1781.658 & 823.6416 & 703.2859 & 215.6383 & 0.957778 & 161.4476 \\
\hline Observations & 60 & 60 & 60 & 60 & 60 & 60 & 60 & 60 \\
\hline
\end{tabular}

Source: Author's computation using EViews

During the period under study, that is from $2002-2016$, the average rate of inflation was about 15.3 percent. The average rate of inflation during the period exceeds the Central Bank targeted inflation rate of a single digit, which is considered as a key convergence criterion for the establishment of the West African Common Currency. The difference between the maximum (32.7) and minimum (8.4) rate of inflation suggests that Ghana's inflation seem to have been very volatile over the study period. Real interest rate measured by the difference between the monetary policy rate and inflation rate over the period averaged 2.8 percent. Relative to the rate of inflation, Ghana's real interest rate has been relatively stable. Real exchange rate over the period also averaged GH\$2.06. Trade as a percentage of GDP over the study period averaged $85 \%$ of GDP. The minimum (6o\%) and maximum (104\%) level of trade to GDP ratio give an indication that Ghana's economy has been relatively open over the study period. International trade tax, which is used as a proxy for international trade policy over the study period, averaged about GH\$190.8 million.

\section{Stationarity Test}

Before estimating the long - and short-run dynamic relationship between trade openness and the effectiveness of monetary policy, the study examined the order 
of integration of the variables employing, the ADF and the KPSS tests. The null hypothesis of the presence of unit root is tested against the alternative of no unit roots in the case of the ADF test. Whereas a null hypothesis of no unit roots is tested against the alternative of unit roots in the case of the KPSS test. The results of the unit root tests are presented in Table 1.

Table 1: Unit root test

\begin{tabular}{|l|l|l|l|l|l|l|l|l|}
\hline \multirow{2}{*}{ Variable } & \multicolumn{2}{|l|}{ Level-ADF } & \multicolumn{2}{l}{ First Difference-ADF } & \multicolumn{2}{l|}{ Level-PP } & \multicolumn{2}{l|}{ First Difference PP } \\
\cline { 2 - 9 } & ADF & Lag & ADF & Lag & KPSS & BW & KPSS & BW \\
\hline & $-2.9465^{\mathrm{b}}$ & 1 & $-5.1408^{\mathrm{a}}$ & 0 & 0.3047 & 5 & 0.0728 & 3 \\
\hline TO & -2.3046 & 10 & -2.3255 & 9 & 0.1780 & 6 & 0.1042 & 5 \\
\hline R & -2.2999 & 0 & $-5.8837^{\mathrm{a}}$ & 0 & 0.4360 & 5 & 0.0627 & 5 \\
\hline RTO & -2.3707 & 0 & $-5.8721^{\mathrm{a}}$ & 0 & 0.4469 & 4 & 0.0628 & 5 \\
\hline & -0.0465 & 0 & $-6.8239^{\mathrm{a}}$ & 1 & 0.5698 & 6 & 0.2413 & 3 \\
\hline & $-7.7062^{\mathrm{a}}$ & 0 & -8.9541 & 1 & 0.0423 & 1 & 0.5000 & 58 \\
\hline DF & $-7.3709^{\mathrm{a}}$ & 0 & $-7.0140^{\mathrm{a}}$ & 3 & 0.4054 & 3 & 0.2269 & 28 \\
\hline
\end{tabular}

Note ${ }^{\mathrm{a}, \mathrm{b}}$ and ${ }^{\mathrm{c}}$ represents significance at $1 \%, 5 \%$ and $10 \%$ levels respectively. Critical Values for KPSS $0.739,0.463$ and 0.347 at $1 \%, 5 \%$ and $10 \%$ respectively.

Source: Author's computation using EViews

The results of the unit roots test indicate inflation rate () and government budget deficit as a percentage of GDP (DF) were the only variables that were stationary at levels based on the ADF test. All other variables, with the exception of trade openness (TO), were stationary after first difference. Given the fact that KPSS test has greater power of test than the ADF, the study proceeded to examine the time series properties of the series employed using the KPSS test. The results of the KPSS test indicates that all variables were stationary at level. The trade policy variable was however stationary after first difference. The results of the unit roots test indicate that the variables employed to estimate the effect of trade openness on the effectiveness of monetary policy is a mixture of both I(1) and I(o) variable. Per the results of the unit roots test, we used the ARDL estimation procedure by Pesaran and Shin (1998) and Pesaran, Shin and Smith (2001).

Table 2: Bounds test for co-integration

\begin{tabular}{|c|c|c|c|c|c|c|c|c|c|}
\hline \multirow[t]{3}{*}{ Model } & \multirow[t]{3}{*}{ K } & \multicolumn{6}{|c|}{ Critical Values } & \multirow[t]{3}{*}{ F-Statistic } & \multirow[t]{3}{*}{ Conclusion } \\
\hline & & \multicolumn{2}{|l|}{$99 \%$} & \multicolumn{2}{|c|}{$95 \%$} & \multicolumn{2}{|c|}{$90 \%$} & & \\
\hline & & I(o) & $\mathbf{I}(\mathbf{1})$ & I(o) & I(1) & I(o) & I(1) & & \\
\hline$\Pi=f\left(T O_{t}, R_{t}, R T O_{t}, r S_{t}, Y_{t}, D F\right)$ & 6 & 2.88 & 3.99 & 2.27 & 3.28 & 1.99 & 2.94 & 13.002 & Co-integrated \\
\hline $\mathbf{Y}_{t}=\boldsymbol{f}\left(\mathrm{TO}, \boldsymbol{R}_{t}, \mathbf{R T O} \boldsymbol{O}_{t}, \boldsymbol{r S}, \boldsymbol{I}_{t}, \mathrm{DF}, \boldsymbol{L}_{t}, K\right)$ & 8 & 2.62 & 3.77 & 2.11 & 3.15 & 1.85 & 2.85 & 13.961 & Co-integrated \\
\hline
\end{tabular}

Source: Author's Computation using EViews 
The results of the Bounds test for co-integration presented in Table 2 indicates the presences of co-integrating relationship in all the estimated models. Specifically, the null hypothesis of no long run relationship between inflation, monetary policy, trade openness as well as other control variable is rejected at 1 percent level of significance. Similarly, the null hypothesis is rejected for the models with output as the dependent variables as well as other control variables. This implies the existence of a long-run co-integrating relationship among the variables of interest, hence the study proceeded to estimate the long-run elasticities and the short run dynamic relationships.

\section{Long-Run Estimates}

Table 3 presents the long run estimates of equations (8) through to (11). All the variables of interest (monetary policy, trade openness and trade policy) were significant and had the expected signs. In equation (8), for example, trade openness (TO) was found to have a negative and significant effect on inflation rate. This implies that greater degree of openness reduces the rate of inflation in Ghana. The result obtained in this study is in line with the theoretical argument of Muellbauer (2007). Muellbauer (2007) argued that greater degree of openness increases the level competition in the market and this tends to reduce the market power of monopolistic firms and suppliers in labour market resulting in some declines in the rate of inflation in the economy. Also, given the fact that large quantities of domestically consumed goods in Ghana are imported, a highly open economy implies more of these goods would be available in the economy with very little room for shortages, contributing to reduction in the rate of inflation. This result is consistent with the findings of Bowdler and Malik (2005), Muellbauer (2007) and Romer (1993). As expected, the effect of real monetary policy rate (R) was found to have negative and significant effect on long run inflation rate. Thus, increases in real monetary policy rate causes inflation rate to decline in the long run. 
Table 3: Long-run estimates

\begin{tabular}{|l|l|l|l|l|}
\hline Regressors & \multicolumn{3}{|c|}{ Dependent Variable $-\Pi_{\mathrm{t}}$} & \multicolumn{2}{l|}{ Dependent Variable $-\boldsymbol{Y}_{\mathrm{t}}$} \\
\hline & \multicolumn{3}{|c|}{$(1)$} & \multicolumn{2}{c|}{$(3)$} \\
\hline & Coef & Std Err & Coef & Std Err \\
\hline & $-0.944^{\mathrm{a}}$ & 0.157 & $0.076^{\mathrm{a}}$ & 0.019 \\
\hline & $-0.444^{\mathrm{a}}$ & 0.047 & $0.031^{\mathrm{a}}$ & 0.006 \\
\hline & $0.448^{\mathrm{a}}$ & 0.052 & $-0.031^{\mathrm{a}}$ & 0.006 \\
\hline & $0.202^{\mathrm{a}}$ & 0.029 & 0.050 & 0.029 \\
\hline & & & 0.047 & 0.036 \\
\hline & 0.065 & 0.117 & & \\
\hline & -0.088 & 0.064 & $0.059^{\mathrm{a}}$ & 0.009 \\
\hline & & & $1.045^{\mathrm{a}}$ & 0.118 \\
\hline D & & & $0.173^{\mathrm{a}}$ & 0.009 \\
\hline C & $-0.378^{\mathrm{a}}$ & 0.047 & $0.008^{\mathrm{b}}$ & 0.003 \\
\hline
\end{tabular}

Note $^{\mathrm{a}, \mathrm{b}}$ and ${ }^{\mathrm{c}}$ represents significance at $1 \%, 5 \%$ and $10 \%$ levels respectively

Source: Author's computation using EViews

The study found a positive relationship between the coefficient of the interacted variables (RTO) and long term inflation rate. The result indicates that simultaneous increase in real monetary policy rate and the degree of openness tend to increase long run inflation rate in Ghana. This is probably due to the fact that increases in real monetary policy rate contributes to the appreciation of the domestic currency and this makes imported goods relatively cheaper. This situation causes an expansion in the importation of goods and services, which eventually contributes to the depreciation of the domestic currency in the end contributing an increase in the rate of inflation. To identify the specific net effect of changes in monetary policy rate on inflation, the study differentiated equation (8) with respect to real monetary policy rate (R) and then analysed its effect at the mean value of trade openness. The result of the net effect indicates that, increases in real monetary policy rate causes long run inflation to decrease by 0.06 standard deviations from average long run inflation in Ghana. Similarly, we analysed the net effect of degree trade openness on inflation at the mean value of real monetary policy rate. The result indicates that increases in the degree of openness causes inflation to increase by o.31 standard deviation from the long run average level of inflation.

The result suggests that trade openness seems to reduce the effectiveness of monetary policy when the net effect of real monetary policy is compared with the coefficient of real monetary policy rate $(\mathrm{R})$ in Table 3 . However, to get the full picture 
of the effect of real monetary policy and degree of openness on inflation, the study analysed the differential of equation (8) with respect to real monetary policy ( $R$ ) and degree of openness (TO) at various degrees of trade openness and levels of real monetary policy respectively.

Figure 2 presents the effect of real monetary policy rate and degree of openness on long run inflation rate taking into account the effect of trade openness and real monetary policy, respectively.

\section{Figure 2: Effect of monetary policy and trade openness on inflation}

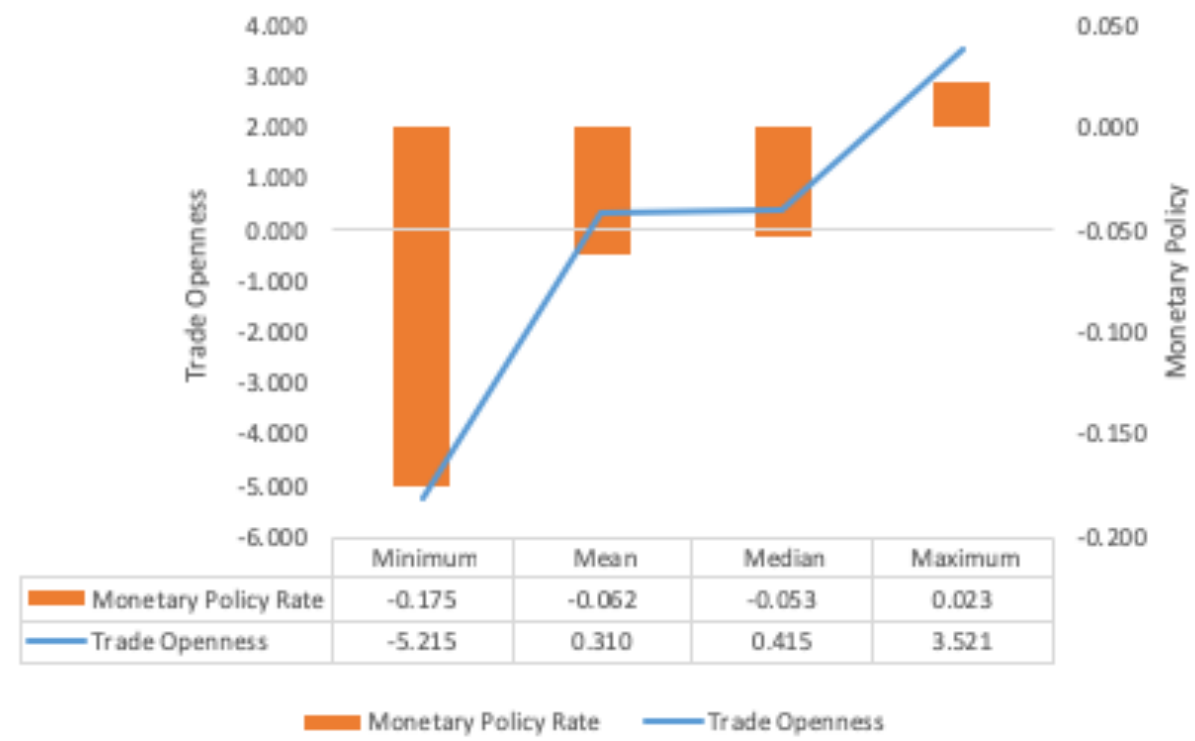

Source: Author's computation

Figure 2 depicts the effect of monetary policy and the degree of openness on Ghana's long-term inflation rate. The effect of monetary policy on inflation rate, taking into account the minimum, mean, median and maximum values of trade openness is captured by the axis on the on the right hand side of Figure 2. The effect of trade openness on long-term inflation taking into account the minimum, mean, median and maximum values of real monetary policy rate is also captured by the left axis. Figure 2 suggests that, high degree of trade openness tends to reduce the effectiveness of monetary policy. Specifically, the minimum value of trade openness, an increase in real monetary policy rate causes inflation to decline by 0.17 standard deviations from the mean value of long-term inflation. However, as the degree of openness increases from the minimum to the maximum, an increase in real monetary policy rate causes long-term inflation to increase by 
0.02 standard deviation from the mean value of inflation. Thus, as the degree of openness increases, increase in the real monetary policy rate contributes to the initial appreciation of the domestic currency, this makes imports much cheaper which in tend worsens the trade balance position of the economy. The worsening trade balance causes depreciation of domestic currency, which leads to an increase in import and input prices as well as agitations for higher wages in the end. This results in higher rates of inflation, making monetary policy ineffective. In terms of trade openness, an increase in the degree of openness, at the minimum value of real monetary policy rate, causes long-term inflation to decline by 5.21 standard deviations from the average long-term inflation in Ghana. However, as real monetary policy rate increases from its minimum value to the maximum value, an increase in the degree of openness causes inflation to increase by 3.52 standard deviations from average long-term inflation rate.

Results obtained in this study bring a different dimension to the literature on the role of trade openness on the effectiveness of monetary policy. Unlike existing studies (mainly Berument et al. (2007) and Karras (1999, 2001)), which mainly focused on advanced export oriented economies, this study focused on a developing economy that is dominated by imports. In addition, existing studies mainly focused on money supply as a measure of monetary policy rather monetary policy rate as used by this study for an inflation targeting economy. The results obtained by the present study shows that contractionary monetary policy could cause inflation to increase in an open economy that is import dependent rather than decline. This is quite different from the results obtained in the literature for expansionary monetary policy in an open economy. Results obtained by Karras (1999, 2001) for example indicated that an expansionary (contractionary) monetary policy in an open economy causes inflation to rise (decline), however results obtained in this study indicate that for a developing economy that is import dependent, contractionary monetary policy becomes ineffective in reducing inflation rate.

In relation to output levels, the study found a positive relationship between trade openness and long-term output. This result implies that an increase in the degree of openness contributes to increases in output levels. Trade openness is known to be associated with the transfer of technology into the domestic economy and also enhances the importation of inputs for the purposes of expanding domestic production (Harrison, 1996). Thus, higher degree of trade openness would lead to a rise in long-term output. Interestingly, the study found a positive relationship between real monetary policy rate and long-term output levels. The results seem to suggest that high real interest rate enhances saving (McKinnon, 2010; Shaw, 1973) which makes funds available for long term investment and this in turn contributes 
to long term growth of output. The interaction between monetary policy rate and trade openness was found to have negative effect on long-term output levels. This implies that simultaneous increase in real monetary policy rate and degree of openness is detrimental to long-term output growth.

The effect of the interaction between real monetary policy rate and trade openness was found to have a negative effect on long-term output. This is probably because of the fact that higher degree of openness that is associated with contractionary monetary policy tends to increase imports, which may cause long run output to decline. Since Ghana has a high demand for imported goods and services, appreciation of the domestic currency, would increase the demand for imports. The high demand for imported goods causes the domestic currency to depreciate, which may contribute to increase the price of imported goods and services, imported inputs as well as agitation for higher wages. This together would cause long-term output to decline. As was done for the inflation model, the study analysed the impact of monetary policy and the degree of openness at various levels of trade openness and monetary policy, respectively.

\section{Figure 3: Effect of monetary policy and trade openness on output}

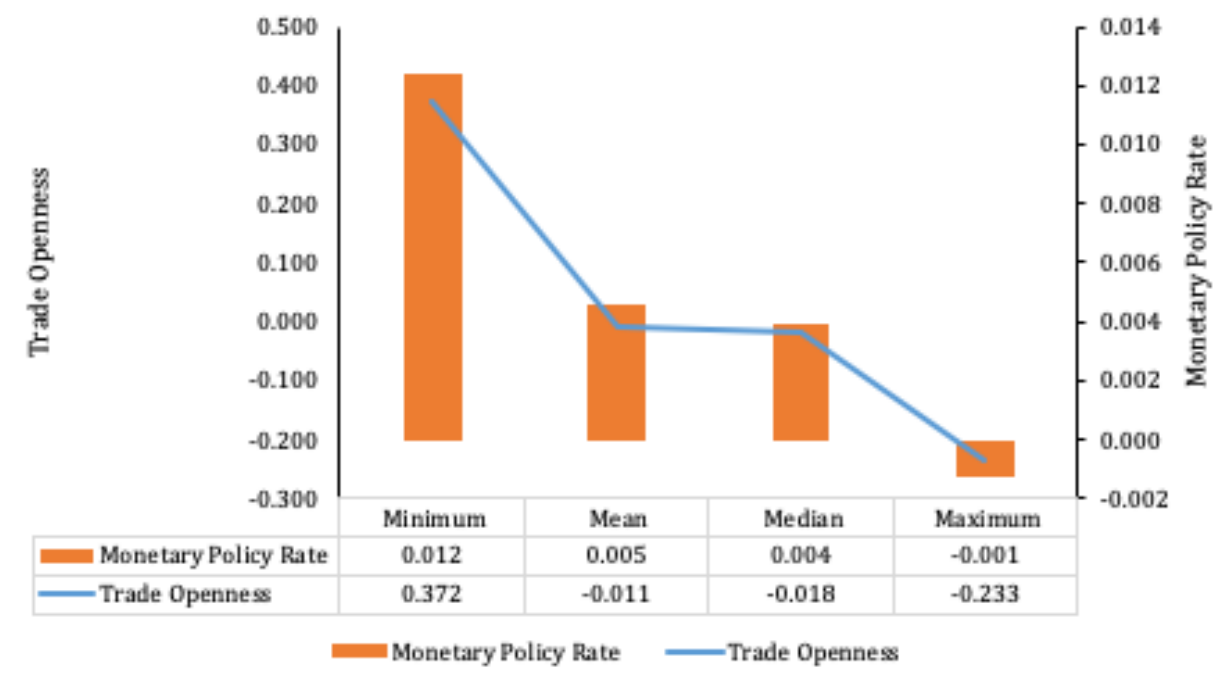

Source: Author's computation

Figure 3 shows the effect of real monetary policy rate and trade openness taking into account the respective role of trade openness and real monetary policy. From the perspective of real monetary policy, the result shows that the adverse effect of contractionary monetary policy on out increases as the degree of openness in the economy also expands. That with greater degree of trade openness, an increase 
in real monetary policy rate causes domestic exports to decline and this worsens the trade balance position of the economy as import expands rapidly which offsets the positive impact of the increase in the real interest rate (increase capital inflows and investments). Similarly, an increase in the degree of trade openness tends to have adverse effect on output as real monetary policy increases from minimum to maximum (see Figure 3). This results is consistent with results obtained by Berument et al. (2007) for Ecuador. Berument et al. (2007) found evidence that trade openness increases the effectiveness of monetary policy in expanding output. Similarly, this study can conclude that trade openness enhances the effectiveness of contractionary monetary policy in Ghana. Trade openness however, makes contractionary monetary policy ineffective in achieving reduction in the rate of inflation in Ghana.

With regard to the control variables in the model, the study found a significant positive relationship between real exchange rate appreciation and inflation. That is, one percent appreciation of the domestic currency causes long run inflation to increase by 0.2 percent. This is because appreciation has an immediate effect of enhancing demand for imported commodities, this causes depreciation of the domestic currency and given the fact that the Ghanaian economy is an import dependent one, such depreciation would cause prices in the market to rise. Thus, appreciation of the domestic currency would in the long-run cause inflation to rise. This result is contrary to results obtained by Adu and Marbuah (2011) for the Ghanaian economy. Though their study covered the period from 1960-2005, their model did not take into account the structural breaks that existed in the economy over the period. More so, their result could be due to the scarcity of foreign exchange in the 1970 and early 1980s, which increased parallel market activities. The real exchange rate had no significant effect on long run output in Ghana. Labour and capital as expected had positive effects on output in Ghana.

\section{Short-Run Dynamics}

The results of the short run estimates are presented in Table 4. The coefficient of the error correction term (ECT) was negative and significant as expected. The error correction term indicates that about 25 percent of the deviations from longrun inflation rate are corrected in the current quarter. The result implies that long equilibrium is restored within a year for the inflation model. The speed of adjustment is much stronger in the output model. The result shows that about 75 of deviations from long-run output are corrected in the short run. The results further show that inflation inertia persists in Ghana's economy. Specifically, previous quarter's inflation rate causes current inflation rate to increase by 0.16 percent. Similarly, economic growth rate in the previous quarter also plays a significant 
role in the current quarter. A percentage increase in economic growth rate in the previous quarter leads to about 0.25 percentage increase in current quarter's growth rate.

The signs of the coefficients of the main variables of interest were the same for inflation rate model. However, signs were mixed in the output model. For example, the first and second lags of trade openness were found to have negative significant effects on economic growth rate contrary to the positive long run effect. This situation could be the result of the immediate adverse effect of high levels of openness on domestic business and firms who may be unable to adjust their production techniques and capacities to compete effectively with imported goods and hence are compelled to reduce their level of production. The effect of trade openness however turns positive in the third quarter, indicating that domestic firms are able to adjust by the third quarter to compete effectively with imported goods. The effect of an increase in real monetary policy was found to be negative and significant at all lags.

Appreciation of the real exchange rate was found to have a significant negative effect on short run inflation after one quarter. Specifically, an appreciation of the real exchange rate by one percent causes short-term inflation to decline by a percentage. An appreciation of the domestic currency implies that imports become relatively cheaper and given the fact that Ghana's economy is import dependent, this tends to reduce short run inflation rate in the economy. Contrary to the short run estimate, the long run results indicate that appreciation of the domestic currency causes inflation to rise. The differences in effect is due to the fact that appreciation of the domestic currency would cause imports to rise and in the long run contribute to the depreciation of the domestic currency, which would in tend increase import prices and increase agitation for higher wages (see Karras, 2001), which would contribute to increase long run inflation. The contemporaneous and the lag effect of the real exchange rate were found to have positive effects on short-run economic growth rate. The contemporaneous effect (0.05) is however greater than the lag effect (o.02). An appreciation of the real exchange rate is usually associated with cheaper imports, hence prices of raw material for domestic production also becomes relatively cheaper and this enhances the growth rate of the economy. 
Table 4: Short run estimates

\begin{tabular}{|c|c|c|c|c|}
\hline \multirow[t]{2}{*}{ Regressors } & \multicolumn{2}{|c|}{ Dependent Variable $-\Pi_{t}$} & \multicolumn{2}{|c|}{ Dependent Variable $-Y_{t}$} \\
\hline & Coef & Std Err & Coef & Std Err \\
\hline & \multicolumn{2}{|l|}{ (1) } & \multicolumn{2}{|l|}{ (2) } \\
\hline$\Delta \Pi_{\mathrm{t}-1}$ & $0.159^{a}$ & 0.029 & & \\
\hline$\Delta \boldsymbol{Y}_{\mathrm{t}-1}$ & & & $0.252^{\mathrm{a}}$ & 0.086 \\
\hline$\Delta \boldsymbol{Y}_{\mathrm{t}-2}$ & & & $-0.150^{c}$ & 0.077 \\
\hline$\Delta \boldsymbol{Y}_{\mathrm{t}-3}$ & & & $0.122^{c}$ & 0.063 \\
\hline$\Delta T O_{t}$ & $-0.271^{b}$ & 0.128 & 0.034 & 0.028 \\
\hline$\Delta T O_{t-1}$ & & & $-0.069^{b}$ & 0.031 \\
\hline$\Delta T O_{t-2}$ & & & $-0.120^{b}$ & 0.048 \\
\hline$\Delta T O_{t-3}$ & & & $0.187^{\mathrm{a}}$ & 0.032 \\
\hline$\Delta T O_{t-1}$ & $-0.109^{a}$ & 0.019 & 0.009 & 0.012 \\
\hline$\Delta \boldsymbol{R} \boldsymbol{O}_{\mathrm{t}}$ & & & $-0.017^{\mathrm{a}}$ & 0.002 \\
\hline$\Delta R O_{t-1}$ & & & $-0.001^{a}$ & 0.000 \\
\hline$\Delta R O_{t-2}$ & $0.061^{a}$ & 0.020 & $-0.009^{a}$ & 0.002 \\
\hline$\Delta R T O_{t}$ & & & $0.017^{\mathrm{a}}$ & 0.002 \\
\hline$\Delta R T O_{t-1}$ & -0.636 & 0.461 & $0.046^{\mathrm{a}}$ & 0.005 \\
\hline$\Delta r S_{t}$ & $-1.087^{b}$ & 0.454 & $0.019^{\mathrm{a}}$ & 0.004 \\
\hline$\Delta r S_{t-1}$ & & & $0.041^{a}$ & 0.005 \\
\hline$\Delta r S_{t-2}$ & & & $0.021^{\mathrm{a}}$ & 0.003 \\
\hline$\Delta \Pi_{\mathrm{t}}$ & & & $0.011^{a}$ & 0.004 \\
\hline$\Delta \Pi_{\mathrm{t}-1}$ & & & $0.027^{\mathrm{a}}$ & 0.005 \\
\hline$\Delta \Pi_{\mathrm{t}-2}$ & & & $-0.010^{a}$ & 0.003 \\
\hline$\Delta \Pi_{\mathrm{t}-3}$ & 2.044 & 4.152 & & \\
\hline$\Delta \boldsymbol{Y}_{\mathrm{t}}$ & $-0.452^{b}$ & 0.176 & $0.006^{a}$ & 0.001 \\
\hline$\Delta D F_{t}$ & & & $-0.030^{a}$ & 0.002 \\
\hline$\Delta \boldsymbol{D} \boldsymbol{F}_{\mathrm{t}-1}$ & & & $-0.016^{a}$ & 0.002 \\
\hline$\Delta D F_{t-2}$ & & & -0.006 & 0.001 \\
\hline$\Delta D F_{t-3}$ & & & -0.068 & 0.127 \\
\hline$\Delta \boldsymbol{L}_{\mathrm{t}}$ & & & $0.054^{a}$ & 0.018 \\
\hline$\Delta \boldsymbol{K}_{\mathrm{t}}$ & & & $-0.047^{c}$ & 0.024 \\
\hline$\Delta \boldsymbol{K}_{\mathrm{t}-1}$ & & & $-0.062^{b}$ & 0.024 \\
\hline$\Delta \boldsymbol{K}_{\mathrm{t}-2}$ & & & $-0.066^{b}$ & 0.021 \\
\hline$D$ & $-2.014^{a}$ & 0.544 & 0.006 & 0.002 \\
\hline$E C T_{t-1}$ & $-0.254^{a}$ & 0.021 & $-0.758^{a}$ & 0.051 \\
\hline
\end{tabular}




\begin{tabular}{|l|l|l|}
\hline Regressors & Dependent Variable $-\boldsymbol{\Pi}_{\mathrm{t}}$ & Dependent Variable $-\boldsymbol{Y}_{\mathrm{t}}$ \\
\hline & Inflation model (1) & Output Gap Model (2) \\
\hline Adjusted & 0.794 & 0.842 \\
\hline F-Stat & $87.854^{\mathrm{a}}$ & $105^{\mathrm{a}}$ \\
\hline DW-Stat & 1.965 & 2.387 \\
\hline AIC & 1.845 & -9.202 \\
\hline SIC & 2.307 & -7.792 \\
\hline LM Serial Corr. test & $2.048[0.141]$ & $1.200[0.290]$ \\
\hline RESET Test & $1.145[0.290]$ & $0.712[0.487]$ \\
\hline Hetro. Test & $7.628[0.813]$ & $0.690[0.832]$ \\
\hline Normality & $1.365[0.505]$ & $0.712[0.487]$ \\
\hline
\end{tabular}

Note $^{\mathrm{a}, \mathrm{b}}$ and ${ }^{c}$ represents significance at $1 \%, 5 \%$ and $10 \%$ levels respectively

Source: Author's computation using EViews

The model diagnostics were also estimated to the short-run estimation results to ensure the reliability of estimated parameters. The results of the post-estimation test indicate that both the output and inflation models passed all specification tests applied. The results show the absence of heteroscedastic errors, serial correlation, model misspecification and non-normality of residuals. The F-statistic for the two models show that they very good fit which confirms their predictive ability. The R-squared values indicate that about 79 and 84 percent of the variations in inflation and output, respectively, are explained by variations in explanatory variables used. The stability test of the two models indicates the absence of structural breaks in the two models estimated (see CUSUM and CUSUMSQ as shown in the figures below). 
Stability Test for Inflation Model
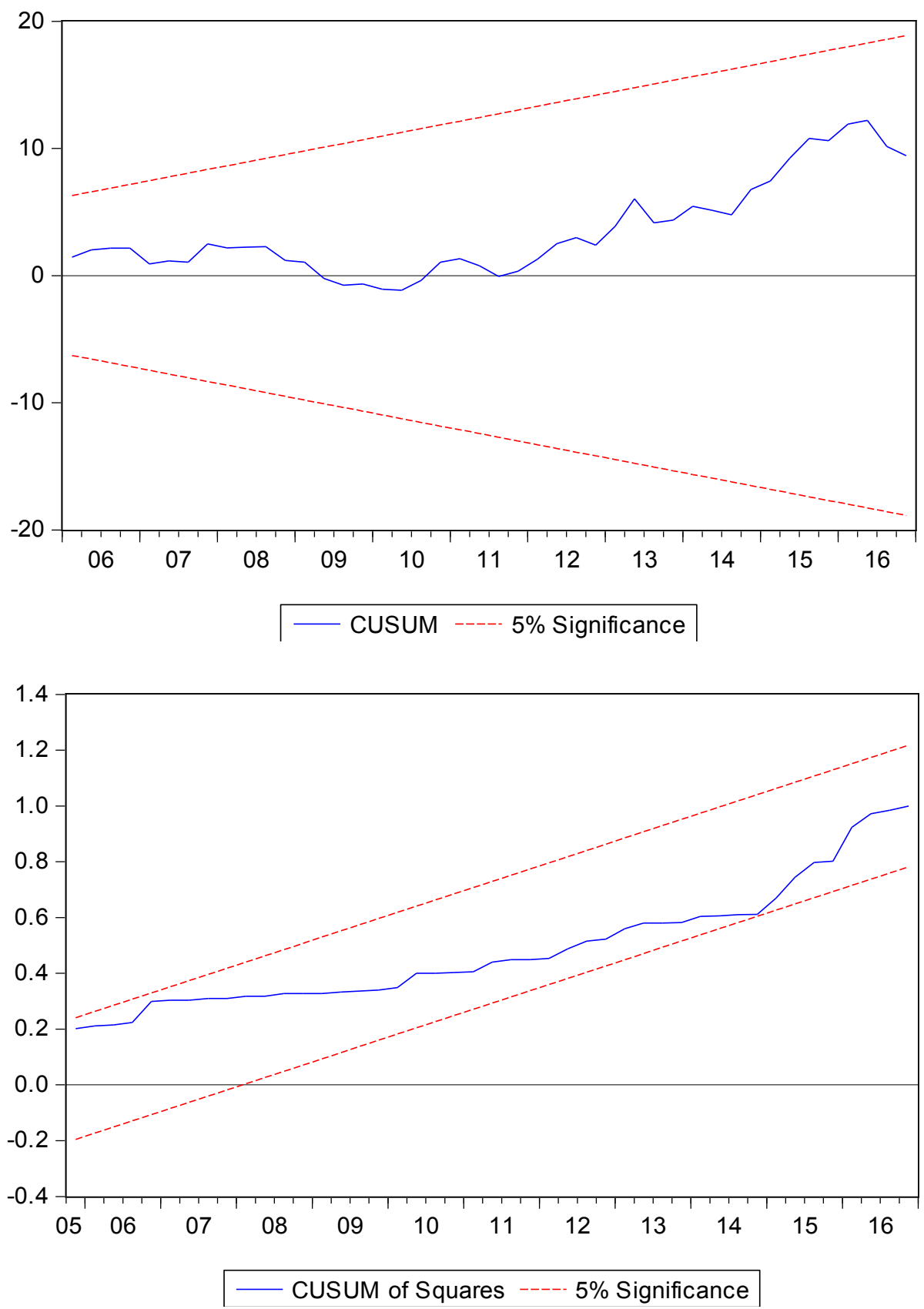
Stability test for output Model
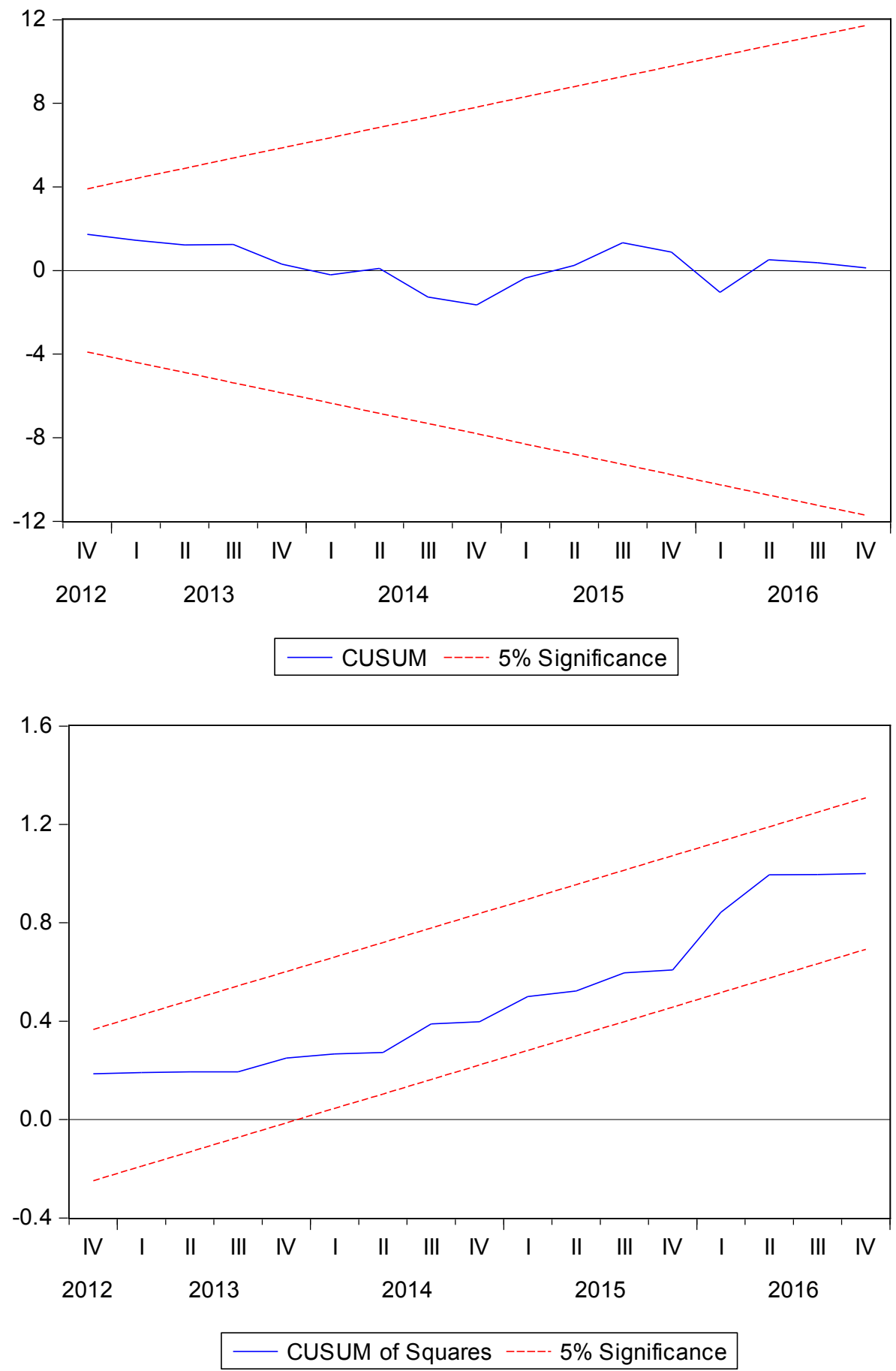


\section{Conclusions and Policy Implications}

The study examined the effectiveness of monetary policy in achieving the policy objective of curtailing inflation considering the role of trade openness. Theoretically, trade openness is expected to diminish the ability of changes in monetary policy rate to influence the level of economic activity. Using quarterly data from 2002 to 2016 for the Ghanaian economy, the study applied the co-integration approach to estimate the effect of monetary policy on inflation and output levels, taking into account the role of trade openness.

The empirical results suggest that monetary policy rate is less effective in reducing inflation rate as expected but it tends to have pronounced effect in reducing the level of output in the economy. That is, monetary policy is less effective in reducing inflation rate in Ghana as the level of openness in the country expands because Ghana's trade has been dominated by imports. As such increases in the monetary policy in an attempt to curtail inflation only ends up in pushing inflation up, this also tend to have adverse effect on output levels as well.

Though the results of the study confirmed the theoretical relationship between trade openness and inflation and output, the result of the study indicated that when monetary policy is taken into account, the negative effect of trade openness on inflation is reduced. That is, the ability of trade openness to reduce inflation level in Ghana is influenced by increases in the monetary policy rate (Figure 2). Similarly, the positive effect of trade openness on output as postulated by economic theory is also reduced as monetary policy rate is increased (Figure 3). This is generally due to the import dominant nature of Ghana's trade.

The results obtained from the study implies that trade openness hinders monetary policy's ability to curtail inflation in Ghana whilst it is able to effectively cause output to decline. Hence, there is need for the Central Bank to consider level of trade openness in the economy when making monetary policy decisions since it tends to have implications for the effectiveness of the policy. In addition, the result of the study implies that Ghana has to increase the export component of its trade to enhance the effectiveness of monetary policy and for the country to derive the full benefits of trade. 


\section{References}

Abradu-Otoo, P., Amoah, B. and Bawumia, M. (2003). An investigation of the transmission mechanisms of monetary policy in Ghana: a structural vector error correction analysis. Bank of Ghana, Working Paper, 2. Retrieved from https://www.bog.gov.gh/privatecontent/Publications/Staff_Working_ Papers/2003/wp-02.pdf Accessed on the 25-06-2016

Adu, G. and Marbuah, G. (2011). Determinants of Inflation in Ghana: An Empirical Investigation. South African Journal of Economics, 79(3), pp. 252-269.

Bawumia, M. (2010). Monetary policy and financial sector reform in Africa: Ghana's experience. Combert Impressions Ghana Ltd. Retrieved from http://www. danquahinstitute.org/docs/MonetaryPolicy\%26FinancialReforminAfrica.pdf

Bawumia, M., Mumuni, Z. and Amoah, B. (2008). Choice of Monetary Policy in Ghana. Bank of Ghana Working Paper.

Berument, H., Konac, N. and Senay, O. (2007). Openness and the effectiveness of monetary policy: A cross-country analysis. International Economic Journal, 21(4), pp. 577-591.

Bowdler, C., and Malik, A. (2005). Openness and inflation volatility: Panel data evidence. University of Oxford. Working Paper. Retrieved from http://www.nuff. ox.ac.uk/Economics/papers/2005/w14/Maydraft2.pdf Accessed on the 26-052016

Calvo, G.A. (1983). Staggered prices in a utility-maximizing framework. Journal of Monetary Economics, 12(3), pp. 383-398.

Dornbusch, R. and Giovannini, A. (1990). Monetary policy in the open economy. Handbook of Monetary Economics, 2, pp. 1231-1303.

Harrison, A. (1996). Openness and growth: A time-series, cross-country analysis for developing countries. Journal of Development Economics, 48(2), 419-447.

Karras, G. (1999). Openness and the effects of monetary policy. Journal of International Money and Finance, 18(1), pp. 13-26.

Karras, G. (2001). Openness to Trade and the Potency of Monetary Policy: How Strong is the Relationship? Open Economies Review, 12(1), pp. 61-73.

Lane, P. (1997). Inflation in Open Economies. Journal of International Economics, 42(34), pp. 327347

McKinnon, R. I. (2010). Money and capital in economic development. Brookings Institution Press. 
Muellbauer, J. (2007). Inflation dynamics and trade openness: with an application to South Africa. Available at https://ora.ox.ac.uk/objects/uuid:3beo5ec8-d4fc4d70-985d-402dcob34dd9 Accessed on the 25-05-2016

Oduro, A. (2000). Performance of the External Trade Sector Since 1970. In Economic Reforms in Ghana: The Miracle \& the Mirage. Accra: Woeli Publishing Services. pp. 168-184.

Pesaran, M.H. and Shin, Y. (1998). An autoregressive distributed-lag modelling approach to cointegration analysis. Econometric Society Monographs, 31, pp. $371-413$.

Pesaran, M.H., Shin, Y. and Smith, R.J. (2001). Bounds testing approaches to the analysis of level relationships. Journal of Applied Econometrics, 16(3), pp. 289326.

Rogoff, K. (1985). The Optimal Degree of Commitment to an Intermediate Monetary Target. The Quarterly Journal of Economics, 100(4), pp. 1169-1189

Romer, D. (1993). Openness and inflation: theory and evidence. The Quarterly Journal of Economics, 108(4), pp. 869-903.

Shaw, E.S. (1973). Financial deepening in economic development. Available at http:// agris.fao.org/agris-search/search.do?recordID=XF2015011329 Accessed on the 26-05-2016

Taylor, J.B. (1993). Discretion versus policy rules in practice. In Carnegie-Rochester conference series on public policy 39, pp. 195-214.

Todaro, M.P. (1992): Economics for Developing World: An Introduction to Principles, Problems and Policies for Development, Third Edition Longmans.

Woodford, M. (2001). The Taylor rule and optimal monetary policy. The American Economic Review, 91(2), pp. 232-237.

World Bank (2016): The World Bank Annual Report. Washington, DC. 